Jurnal Sain Veteriner, Vol. 37. No. 2. Desember 2019, Hal. 185-192

DOI: $10.22146 /$ jsv. 34463

ISSN 0126-0421 (Print), ISSN 2407-3733 (Online)

Tersedia online di https://jurnal.ugm.ac.id/jsv

\title{
Deteksi Kejadian Residu Tetrasiklin pada Daging Ikan Nila di Kota Yogyakarta dengan Kromatografi Cair Kinerja Tinggi (KCKT)
}

\section{Detection of Tetracycline Residue on Tilapia Meat in Kota Yogyakarta using High Performance Liquid Chromatography (HPLC)}

\author{
Wari Pawestri ${ }^{1}$, Gagak Donny Satria $\uparrow^{2}$, Nisa Hakimah ${ }^{3}$, Doddi Yudhabuntara ${ }^{4}$ \\ ${ }^{1}$ Program Studi Peternakan, Fakultas Pertanian, Universitas Sebelas Maret, \\ J1. Ir Sutami No.36 A, Pucangsawit, Jebres, Surakarta, Jawa Tengah 57126 \\ ${ }^{2}$ Departemen Farmakologi, Fakultas Kedokteran Hewan, Universitas Gadjah Mada, \\ Jl. Fauna 2 Karangmalang, Depok, Sleman, Yogyakarta \\ ${ }^{3}$ Program Studi Teknik Penanganan Patologi Perikanan, Politeknik Kelautan dan Perikanan Sidoarjo, \\ Jl. Raya Buncitan, Gedangan, Dusun Kp. Baru, Buncitan, Sidoarjo, Jawa Timur 61254 \\ ${ }^{4}$ Departemen Kesehatan Masyarakat Veteriner, Fakultas Kedokteran Hewan, Universitas Gadjah Mada, \\ Jl. Fauna 2 Karangmalang, Depok, Sleman, Yogyakarta \\ 'Email: wari.pawestri@staff.uns.ac.id
}

Naskah diterima: 31 Maret 2018, direvisi: 21 Januari 2018, disetujui: 30 November 2019

\begin{abstract}
Food products of animal origin which are free from biological and chemical contamination are an absolute requirement of food safety. Antibiotics residues in the food of animal origin is one of the chemical contaminants in food are harmful/hazardous to human health. Tetracycline is an antibiotic that is often used in the fishing industry. The study aims to detect the occurrence of tetracycline residues in tilapia sold in traditional markets in Kota Yogyakarta. The research was conducted with detection test (detect disease). The study used 61 samples of tilapia fish from 16 traditional markets in Kota Yogyakarta. Tilapia meat samples are prepared according to the Association of Official Analytical Chemistry (AOAC). The existence of tetracycline residues in meat can be detected by high performance liquid chromatography (HPLC). Residue analysis in fish meat was conducted at the Department of Pharmacology, Faculty of Veterinary Medicine of Gadjah Mada University using HPLC Shimadzu version 6.1. The results showed that 24 samples of tilapia meat marketed in Kota Yogyakarta was positively contained tetracycline antibiotic residues. A total of 19 samples contained residues above maximum residue limits (MRL). The conclusion of the study is $31 \%$ of tilapia marketed in Kota Yogyakarta contains tetracycline residues above MRL. Surveillance of residues in food of animal origin and further research in terms of reducing antibiotic residue in tilapia meat is highly recommended to improve the quality and safety of food of animal origin.
\end{abstract}

Key words: HPLC; meat; residue; tetracycline; tilapia

\begin{abstract}
Abstrak
Produk pangan asal hewan yang bebas dari cemaran biologi dan kimia merupakan syarat mutlak keamanan pangan asal hewan. Keberadaan residu antibiotik dalam pangan asal hewan merupakan salah satu cemaran kimia yang membahayakan kesehatan manusia. Tetrasiklin adalah antibiotik yang sering digunakan pada industri perikanan. Penelitian bertujuan untuk mendeteksi kejadian residu tetrasiklin pada ikan nila yang dipasarkan di pasar tradisional Kota Yogyakarta. Penelitian menggunakan 61 sampel ikan nila dari 16 pasar tradisional di Kota Yogyakarta. Sampel daging ikan nila dipreparasi berdasarkan standar Association of Official Analytical Chemistry $(\mathrm{AOAC})$. Keberadaan residu tetrasiklin dalam daging ikan nila dapat diperiksa dengan alat kromatografi cair kinerja tinggi (KCKT). Analisis residu pada daging ikan dilakukan di Laboratorium Farmakologi Fakultas Kedokteran Hewan Universitas Gadjah Mada dengan menggunakan KCKT Shimadzu versi 6.1. Hasil analisis menunjukkan bahwa 24 sampel daging ikan nila yang dipasarkan di Kota Yogyakarta terdeteksi mengandung
\end{abstract}


residu antibiotik tetrasiklin. Sebanyak 19 sampel mengandung residu di atas batas maksimum residu (BMR). Kesimpulan dari penelitian bahwa 31\% ikan nila yang dipasarkan di Kota Yogyakarta positif mengandung residu antibiotik tetrasiklin di atas BMR. Pengawasan residu dalam pangan asal hewan dan penelitian lanjutan terkait upaya pengurangan residu pada daging ikan nila sangat disarankan untuk meningkatkan mutu dan keamanan pangan asal hewan.

Kata kunci: daging; KCKT; nila; residu; tetrasiklin

\section{Pendahuluan}

Indonesia sebagai negara maritim dengan dua pertiga bagian perairan memegang peranan penting dalam penyedia produk pangan asal hewan terutama ikan. Ikan nila merupakan salah satu komoditas ikan air tawar yang banyak dibudidayakan di Indonesia. Ikan nila menjadi primadona karena mudah dipelihara, tahan terhadap lingkungan buruk, laju pertumbuhan cepat, daging tebal dan padat, kandungan gizi tinggi (protein 52,46\%), serta harga terjangkau (Ardita dkk., 2015). Tingkat konsumsi ikan di Indonesia terus meningkat seiring dengan peningkatan kesadaran masyarakat terhadap manfaat mengonsumsi ikan (Kementrian Kelautan dan Perikanan, 2016).

Angka konsumsi ikan di Daerah Istimewa Yogyakarta tahun 2017 sebesar 23,75 kg per kapita. Angka tersebut mengalami peningkatan dari tahun sebelumnya yaitu sebesar $23,10 \mathrm{~kg}$ per kapita pada tahun 2016 dan sebesar 23,07 kg per kapita tahun 2015 (Kementerian Kelautan dan Perikanan, 2018). Ikan lele, ikan nila, dan ikan gurami merupakan ikan budi daya yang dominan dikonsumsi masyarakat Kota Yogyakarta. Produksi ikan nila di Yogyakarta mencapai 21.000 ton dari total produksi sebesar 36.280 ton (Nurwigati, 2017).

Peningkatan konsumsi ikan harus diimbangi dengan peningkatan mutu dan keamanan pangan. Menurut Peraturan Pemerintah Nomor 28 tahun 2004, pangan yang aman, bermutu, dan bergizi sangat penting peranannya bagi pertumbuhan, pemeliharaan, peningkatan derajat kesehatan, serta peningkatan kecerdasan masyarakat. Persyaratan keamanan pangan harus dipenuhi untuk melindungi masyarakat dari pangan yang merugikan dan membahayakan kesehatan, baik karena cemaran biologis, kimia, maupun benda lain yang dapat mengganggu, merugikan, dan membahayakan kesehatan manusia (Republik Indonesia, 2004).

Residu antibiotik merupakan salah satu cemaran kimia dalam pangan yang mengancam kesehatan manusia (Dewi dkk., 2014). Ancaman tersebut meliputi efek toksik, keracunan, gangguan pencernaan, gagalnya pengobatan akibat resistensi, dan gangguan mikroflora dalam saluran pencernaan (Yuningsih, 2004; Anastasia, 2011; dan Dasenaki dan Thomaidis, 2015). Masalah residu antibiotik erat kaitannya dengan penggunaan antibiotik tanpa pengawasan dan tidak terkontrol yang mengakibatkan akumulasi antibiotik pada jaringan/organ hewan (Lukistyowati dan Syawal, 2013). Tetrasiklin merupakan antibiotik yang banyak digunakan $(60 \%$ dari keseluruhan pemakaian antibiotik) pada budi daya perikanan (Sekkin dan Cavit, 2011) sebagai pencegahan, terapi, dan peningkatan laju pertumbuhan (Yuningsih, 2004; Canada dkk., 2009; Evaggelopoulou dan Samanidou, 2013). Tetrasiklin banyak digunakan karena memiliki spektrum luas yang berperan melawan bakteri Gram positif dan Gram negatif serta memiliki harga terjangkau (Orlando dan Samionato, 2013).

Tetrasiklin merupakan basa yang sukar larut dalam air, tetapi bentuk garam natrium atau garam $\mathrm{HCl}$ nya mudah larut. Tetrasiklin memiliki rumus molekul $\mathrm{C}_{22} \mathrm{H}_{24} \mathrm{~N}_{2} \mathrm{O}_{8}$ dengan berat molekul 444,44 g/mol (Wang dkk., 2012). Struktur kimia tetrasiklin ditunjukkan pada Gambar 1. Potensi tetrasiklin berkurang dalam larutan dengan $\mathrm{pH}$ kurang dari/sama dengan dua ( $\leq$ 2) dan mudah rusak dalam larutan alkali hidroksida. Kelarutan tetrasiklin dalam air sebesar $1,7 \mathrm{mg} / \mathrm{ml}$ dan kelarutan dalam metanol lebih dari $2 \mathrm{mg} / \mathrm{ml}$ pada suhu $28^{\circ} \mathrm{C}$ (Wang dkk., 2012).

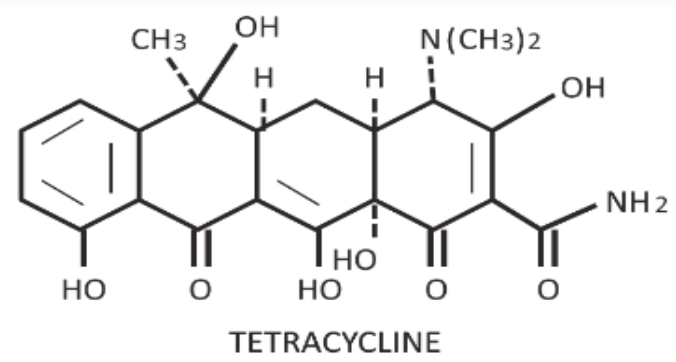

Gambar 1. Struktur kimia tetrasiklin (Griffin dkk., 2010) 
Batas maksimum residu tetrasiklin yang ditetapkan oleh Badan Standardisasi Nasional (2000) untuk daging adalah $0,1 \mathrm{mg} / \mathrm{kg}$. Menurut Orlando dan Samionato (2013) batas maksimum residu (BMR) tetrasiklin pada daging ikan adalah $2 \mathrm{mg} / \mathrm{kg}$. Codex Alimentarius Comission (2017) menentukan BMR untuk golongan tetrasiklin sebesar $200 \mu \mathrm{g} / \mathrm{kg}$ pada daging ikan.

Keberadaan residu obat hewan terutama antibiotik pada produk pangan asal hewan telah banyak dilaporkan. Penelitian yang dilakukan oleh Nurhasnawati dkk. (2016) menyatakan bahwa sampel ikan air tawar di Pasar Segiri, Samarinda, Kalimantan Timur mengandung residu tetrasiklin. Barani dan Fallah (2015) melakukan penelitian terhadap ikan trout di Iran dan terdeteksi 86 dari 138 sampel mengandung residu tetrasiklin.

Berkaitan dengan hal tersebut, pengawasan residu terhadap pangan asal hewan sangat penting sebagai upaya menghasilkan pangan yang aman dikonsumsi masyarakat. Salah satu cara yang dapat dilakukan adalah dengan mendeteksi kejadian residu dalam produk perikanan, terutama dari kegiatan budi daya (akuakultur). Keberadaan residu antibiotik golongan tetrasiklin dalam bahan pangan perlu dideteksi secara akurat, efektif, dan efisien. Kromatografi cair kinerja tinggi merupakan teknologi pemisahan senyawa yang memiliki kecepatan, kepekaan, dan ketelitian tinggi (Rohman, 2009).

Penelitian bertujuan untuk mendeteksi kejadian residu tetrasiklin pada ikan nila yang dipasarkan di Kota Yogyakarta. Hasil penelitian yang diperoleh diharapkan dapat meningkatkan kesadaran dan kepedulian masyarakat terhadap masalah-masalah keamanan pangan serta meningkatkan mutu dan status keamanan pangan asal hewan.

\section{Materi dan Metode}

Penelitian dilakukan di Laboratorium Farmakologi Fakultas Kedokteran Hewan Universitas Gadjah Mada pada bulan Januari sampai dengan bulan Februari 2018. Penelitian lapangan dilakukan dengan mendeteksi kejadian residu tetrasiklin pada ikan nila yang diedarkan di pasar tradisional Kota Yogyakarta.

Sampel ikan nila sebanyak 61 ekor dengan berat antara $350-450 \mathrm{~g}$ dari 16 pasar tradisional di Kota Yogyakarta digunakan dalam penelitian ini. Bahan lain yang digunakan dalam penelitian adalah methanol (methyl alcohol, HPLC grade, J.T. Baker), acetonitrile (HPLC grade, Macron), Oxalic acid, crystal (HOCOCOOH.2 $\left.\mathrm{H}_{2} \mathrm{O}\right)$ (J.T. Baker), di-Sodium hydrogen phosphate $\left(\mathrm{Na}_{2} \mathrm{HPO}_{4}\right)$ (Merck, Germany), Citric acid monohydrate (Merck, Germany), Titriplex III ( $\left.\mathrm{Na}_{2} \mathrm{EDTA}\right)$ (ethylenedinitrilo-tetraacetic acid, Merck, Germany), dan aquabidestilata sterile proinjection (PT. Ikapharmindo Putramas, Jakarta, Indonesia).

Alat yang digunakan untuk menganalisis residu antibiotik tetrasiklin adalah seperangkat alat kromatografi cair kinerja tinggi (KCKT) di Laboratorium Farmakologi, Fakultas Kedokteran Hewan, Universitas Gadjah Mada merek Shimadzu 6.1 dengan system control SCL-10A VP, detector UV-Vis SPD 10-AV VP, pompa LC-10AD VP, degasser DGU-14A, oven CTO-10AC VP dan kolom $\mathrm{C}_{18}$ Clipeus, syringe 25F-LC, sumber energi (power supply), wadah fase gerak, dan komputer. Alat penunjang yang digunakan adalah ultrasonic bath (Elma), labu ukur (Pyrex), timbangan digital (Ohaus), spatula, gelas ukur, gelas bekker, labu erlenmeyer (Pyrex), vortex mixer (Maxi Mix II), sentrifuse (PLC series), pisau, talenan, kertas perkamen, kertas saring, rak tabung, batang pengaduk, sendok tanduk, tabung konikel atau tabung sentrifus, timer, dan plastik silk. Pengambilan sampel lapangan menggunakan kantong plastik, label, alat tulis, selotip, dan lembar kuesioner.

Besar sampel minimal ikan nila dalam penelitian dihitung dengan menggunakan rumus detect disease $\mathrm{n}$ $\left.=\left[1-(1-a)^{1 / D}\right)\right][N-(D-1) / 2]$ dengan asumsi prevalensi residu tetrasiklin sebesar 30\% (Olatoye dan Afisu, 2013) dan tingkat kepercayaan $95 \%$. Jumlah sampel ikan nila yang diambil (n) minimal delapan (8) ekor. Unit terkecil dalam penelitian adalah penjual ikan dan sampel ikan sejumlah satu (1) ekor dari setiap penjual dipilih secara random. Penelitian menggunakan 61 sampel ikan nila dari 61 penjual di 16 pasar tradisional di Kota Yogyakarta.

Sampel daging ikan nila dipreparasi sebelum dianalisis dengan alat kromatografi cair kinerja tinggi (KCKT). Preparasi jaringan yang dilakukan berdasarkan standar Association of Official Analytical Chemistry (AOAC) internasional untuk golongan tetrasiklin.

Sampel jaringan ikan nila seberat $1 \mathrm{~g}$ dihaluskan dan dimasukkan ke dalam tabung konikel I. Tabung konikel I ditambah dengan $5 \mathrm{ml}$ bufer Mcllvaine dan dihomogenkan dengan menggunakan vortex mixer selama 30 detik. Tabung konikel I ditambah dengan 4 ml bufer Mcllvaine selanjutnya dihomogenkan dengan 
vortex mixer selama 30 detik dan disentrifus 10 menit 2500 g. Supernatan dari tabung konikel I disaring ke dalam tabung konikel II. Homogenat tabung konikel I ditambah dengan $4 \mathrm{ml}$ bufer McIlvaine selanjutnya dihomogenkan dengan vortex mixer selama 30 detik dan disentrifus 10 menit 2500 g. Supernatan dari tabung konikel I disaring kembali ke dalam tabung konikel II. Tabung konikel I ditambahkan dengan 2 $\mathrm{ml}$ bufer McIlvaine, dihomogenkan, dan disentrifus (vortex mixer selama 30 detik, sentrifus 10 menit 2500 g). Supernatan ditambahkan kembali ke tabung konikel II. Tabung konikel II disentrifus selama 20 menit 2500 g. Supernatan kolektif tabung konikel II disaring ke tabung konikel I yang telah dicuci dan disterilkan.

Larutan bufer McIlvaine merupakan larutan yang digunakan dalam preparasi sampel jaringan ikan nila. Larutan bufer Mcllvaine dibuat dengan melarutkan $28,41 \mathrm{~g}$ di-Sodium hydrogen phosphate $\left(\mathrm{Na}_{2} \mathrm{HPO}_{4}\right)$ dalam 11 aquabidestilata sebagai larutan pertama. Citric acid sebanyak 21,01 g dilarutkan dalam 1 1 aquabidestilata sebagai larutan kedua. Larutan pertama sebanyak $625 \mathrm{ml}$ dicampurkan dengan 11 larutan kedua sampai tercampur merata sebagai larutan ketiga. Langkah terakhir dengan mencampurkan $60,49 \mathrm{~g} \mathrm{Na}_{2}$ EDTA dalam larutan ketiga sampai larut sempurna (Badan Standardisasi Nasional, 2009). Bufer McIlvaine dimasukkan dalam ultrasonic bath selama 15 menit dengan suhu $30^{\circ} \mathrm{C}$.

Daging ikan nila hasil preparasi diuji dengan kromatografi cair kinerja tinggi (KCKT). Prosedur pengoperasian alat KCKT untuk menganalisis kadar residu tetrasiklin dalam daging ikan dilakukan dengan menggunakan kolom Clipeus suhu $30^{\circ} \mathrm{C}$, laju alir $1 \mathrm{ml} /$ menit, detektor UV-Vis dengan panjang gelombang $355 \mathrm{~nm}$, dan fase gerak campuran dari methanol:acetonitril:larutan oxalic acid $0,126 \%$ dengan perbandingan 5:15:80. Injeksi sampel ke KCKT sebanyak $20 \mu \mathrm{l}$ dari masing-masing sampel.

Analisis sampel dengan KCKT menunjukkan hasil positif apabila kromatogram dengan profil spesifik tetrasiklin muncul pada waktu retensi antara menit ke-5 hingga menit ke-6. Data hasil penelitian mengenai kejadian residu antibiotik tetrasiklin pada daging ikan nila di pasar tradisional Kota Yogyakarta dianalisis secara deskriptif.

\section{Hasil dan Pembahasan}

Penelitian deteksi kejadian residu antibiotik tetrasiklin pada daging ikan nila dilakukan pada 16 pasar tradisional di Kota Yogyakarta. Jumlah sampel ikan nila yang digunakan dalam penelitian berjumlah 61 ekor (minimal jumlah sampel untuk keperluan detect disease adalah 8). Pengisian kuesioner dan wawancara kepada penjual ikan dilakukan untuk melengkapi informasi. Data terkait sampel ikan nila pada 16 pasar tradisional disajikan dalam Tabel 1.

Ikan nila yang diperjualbelikan di pasar tradisional Kota Yogyakarta merupakan produk budi daya perikanan yang berasal dari 13 kota di Jawa Tengah, Jawa Timur, dan Daerah Istimewa Yogyakarta (DIY). Sebanyak 31\% ikan nila berasal dari Klaten, $20 \%$ dari Semarang, masing-masing 6\% dari Sleman dan Yogyakarta, 5\% dari Boyolali dan Wonogiri, serta $13 \%$ campuran dari Tulungagung, Solo, Sragen, Bantul, Purwodadi, Ambarawa, dan Kuningan.

Gambar 2 menunjukkan kromatogram sampel daging ikan nila yang positif mengandung residu antibiotik tetrasiklin. Area puncak spesifik tetrasiklin muncul pada waktu retensi antara menit ke-5 sampai dengan menit ke-6. Hasil analisis peak standar tetrasiklin ditunjukkan pada Gambar 3. Gambar 4 menunjukkan kromatogram sampel daging ikan nila yang tidak mengandung residu antibiotik tetrasiklin.

Tabel 1. Data sampel ikan nila

\begin{tabular}{|c|c|c|}
\hline Pasar & $\begin{array}{l}\text { Jumlah } \\
\text { Sampel }\end{array}$ & Asal Ikan \\
\hline Demangan & 11 & $\begin{array}{l}\text { Boyolali, Wonogiri, Kota } \\
\text { Yogyakarta, Klaten, } \\
\text { Semarang }\end{array}$ \\
\hline Kranggan & 11 & $\begin{array}{c}\text { Sleman, Semarang, Solo, } \\
\text { Wonogiri, Boyolali, } \\
\text { Tulungagung }\end{array}$ \\
\hline Bringharjo & 7 & Semarang, Klaten \\
\hline Lempuyangan & 2 & Bantul, Sragen \\
\hline Ngasem & 2 & Kota Yogyakarta, Klaten \\
\hline Gedongkuning & 1 & Klaten, Boyolali \\
\hline Legi & 3 & $\begin{array}{c}\text { Kota Yogyakarta, } \\
\text { Purwodadi, Semarang }\end{array}$ \\
\hline Prawirotaman & 4 & $\begin{array}{c}\text { Klaten, Semarang, } \\
\text { Ambarawa }\end{array}$ \\
\hline Serangan & 1 & Klaten \\
\hline Sentul & 5 & $\begin{array}{l}\text { Klaten, Kuningan, } \\
\text { Wonogiri, Solo }\end{array}$ \\
\hline Ngadikusuman & 2 & Semarang, Klaten \\
\hline Giwangan & 3 & Klaten, Wonogiri \\
\hline Kotagede & 4 & $\begin{array}{c}\text { Boyolali, Semarang, } \\
\text { Boyolali }\end{array}$ \\
\hline Gondomanan & 1 & Kota Yogyakarta \\
\hline Karangwaru & 2 & Klaten \\
\hline Talok & 2 & Klaten, Sleman \\
\hline Total Sampel & 61 & \\
\hline
\end{tabular}




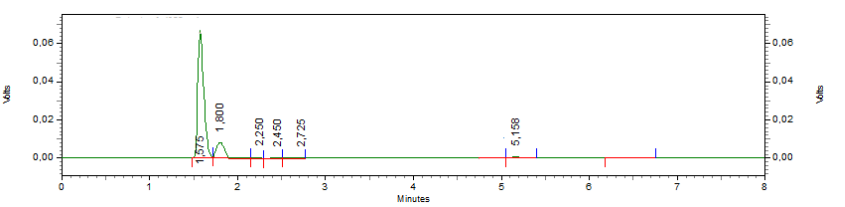

Gambar 2. Kromatogram sampel daging ikan nila positif residu antibiotik tetrasiklin

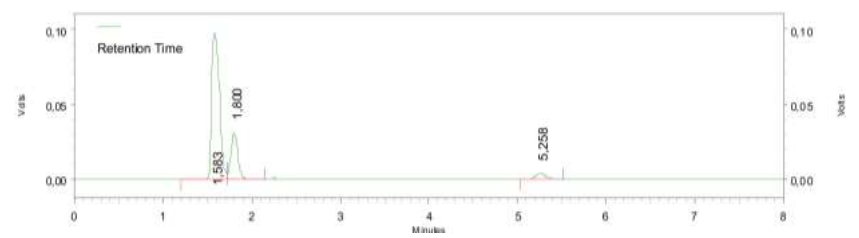

Gambar 3. Kromatogram tetrasiklin murni konsentrasi 0,175 $\mu \mathrm{g} / \mathrm{ml}$

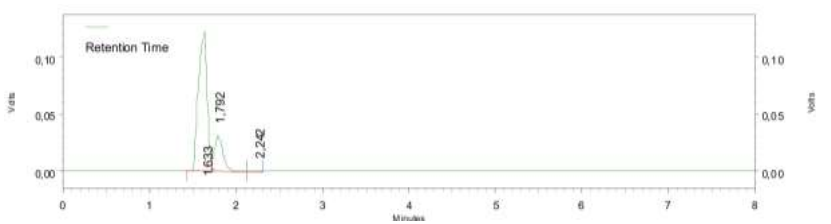

Gambar 4. Kromatogram sampel daging ikan tidak mengandung residu antibiotik tetrasiklin

Area puncak tidak muncul pada retensi waktu antara menit ke-5 sampai dengan menit ke-6.

Hasil analisis dengan KCKT menunjukkan bahwa ikan nila yang dipasarkan di Kota Yogyakarta mengandung residu antibiotik tetrasiklin. Sebanyak 24 sampel daging ikan nila positif mengandung residu antibiotik tetrasiklin dan 19 sampel dari 24 sampel yang positif mengandung residu antibiotik memiliki kadar residu tetrasiklin di atas batas maksimum residu (BMR) yang diizinkan (31\%). Sampel tersebut berasal dari Ambarawa, Boyolali, Klaten, Semarang, Sleman, Tulungagung, dan Wonogiri. Batas maksimum residu adalah batas konsentrasi maksimum analit yang diperbolehkan berada pada ikan konsumsi hasil pembudidayaan (Daghrir dan Drogul, 2013). Badan Standardisasi Nasional (2000) menetapkan BMR untuk tetrasiklin pada daging $0,1 \mathrm{mg} / \mathrm{kg}$.

Konsumsi pangan asal hewan yang mengandung antibiotik diperbolehkan asalkan berada di bawah batas maksimum residu yang ditetapkan (Nurhasnawati dkk., 2016). Residu antibiotik merupakan salah satu cemaran kimia dalam pangan asal hewan yang mengancam kesehatan manusia (Dewi dkk., 2014). Daging dengan residu melewati BMR tidak aman dikonsumsi karena menyebabkan reaksi alergi, keracunan, gagalnya pengobatan akibat resistensi, gangguan jumlah mikroflora, dan gangguan fisiologis pada manusia. Penggunaan antibiotik pada hewan berhubungan dengan munculnya kejadian resistensi pada manusia dan hewan. Okocha (2018) mengungkapkan bahwa peningkatan kejadian resistensi antibiotik pada manusia dan hewan sebagai akibat meluasnya penggunaan antibiotik dalam budi daya perikanan di Cina.

Ikan nila yang diperjualbelikan di Kota Yogyakarta belum bebas dari residu antibiotik tetrasiklin. Keberadaan residu antibiotik berkaitan dengan penggunaan antibiotik dalam budi daya perikanan (Nurhasnawati dkk., 2016). Pembudidaya beranggapan bahwa antibiotik merupakan solusi utama dalam pengobatan penyakit ikan dan peningkatan hasil produksi perikanan. Antibiotik bisa diberikan secara terpisah atau melalui pakan. Penggunaan antibiotik tidak sesuai aturan, tanpa pengawasan, dan tidak terkontrol mengakibatkan akumulasi antibiotik pada jaringan dan organ hewan (Lukistyowati dan Syawal, 2013). Perhatian peternak yang kurang terkait waktu henti obat, sebagai contoh pemanenan ikan sebelum waktu henti obat terpenuhi juga berkorelasi dengan kejadian residu antibiotik dalam produk pangan asal hewan.

Keberadaan residu antibiotik pada daging ikan nila yang dipasarkan di Kota Yogyakarta dapat disebabkan oleh beberapa dugaan. Dugaan pertama penggunaan antibiotik sebagai bahan tambahan pakan. Reda dkk. (2013) menjelaskan bahwa penggunaan antibiotik pada pakan di industri perikanan sebagai growth promotor lebih sering daripada pengobatan. Ikan nila yang dipasarkan di Kota Yogyakarta belum tentu mengalami masalah kesehatan. Dugaan kedua adalah adanya kontaminasi antibiotik pada air yang digunakan sebagai pemeliharaan ikan. Antibiotik yang sudah dicerna di dalam tubuh ikan akan dikeluarkan sebagai produk sisa. Zhao dkk. (2015) menjelaskan bahwa sisa antibiotik yang sudah dimetabolisme dapat terakumulasi di air maupun tanah sebagai endapan. Limbah antibiotik yang tidak diolah di pengolahan limbah air dengan tepat dapat mencemari perairan lain seperti sungai dan kolam-kolam budi daya ikan yang lain. Antibiotik golongan tetrasiklin umumnya termasuk antibiotik yang tetap stabil ketika larut dalam air (Noga, 2010). Dugaan ketiga adalah adanya endapan sisa antibiotik yang mencemari tanah di kolam. Antibiotik hasil metabolisme maupun sisa pakan yang masih aktif dapat mengendap di tanah maupun dasar kolam yang berstruktur tanah (Koleva. 2014). Noga (2010) menjelaskan bahwa antibiotik golongan tetrasiklin dapat mengikat komponen 
organik (feses) maupun tanah dan mengendap di dasar kolam. Akumulasi endapan secara terus-menerus dapat meningkatkan konsentrasi antibiotik di dalamnya.

Antibiotik tetrasiklin dapat masuk ke dalam tubuh melalui penyerapan dari air, secara injeksi, maupun per oral (Noga, 2010). Kadar residu tetrasiklin pada ikan nila yang diinjeksi lebih tinggi dibandingkan dengan ikan nila yang diberi antibiotik secara per oral. Farmakokinetik antibiotik injeksi lebih cepat dibandingkan dengan antibiotik yang diberikan secara per oral. Antibiotik yang diberikan secara per oral masuk ke saluran pencernaan, lambung, dan usus. Absorpsi tetrasiklin secara per oral terutama di usus halus bagian atas. Tetrasiklin dapat diabsorpsi 60$80 \%$ melalui saluran gastrointestinal (Kee dan Hayes, 1994). Makanan yang mengandung protein, lemak, karbohidrat, susu, atau kation (kalsium, magnesium, ferum, dan aluminium) menyebabkan terbentuknya kompleks pengkelat dan menurunkan tingkat absorpsi tetrasiklin hingga $50 \%$. Tetrasiklin yang terabsorpsi akan terikat pada plasma protein dengan persentase 28-41\% (Wang dkk., 2012).

Hepatopankreas merupakan organ utama detoksifikasi obat pada ikan seperti halnya mamalia. Metabolisme ikan terdiri dari dua fase, yakni fase I (oksidasi, reduksi, dan hidrolisis) serta fase II (konjugasi). Reaksi tersebut yang menyebabkan ikan mampu mendetoksifikasi maupun mengaktifkan obat (Noga, 2010). Tetrasiklin dieliminasi melalui filtrasi glomeruli, empedu, dan insang (Noga, 2010). Sebanyak 50-80\% tetrasiklin (Plumb, 1999) diekskresikan dalam bentuk aktif ke lingkungan melalui urin dan feses, sebagian kecil tetrasiklin dimetabolisme menjadi senyawa tidak aktif (inactive), dan $10-20 \%$ diekskresikan melalui cairan empedu (Deck dan Winston, 2012).

Tetrasiklin mudah larut dalam lemak serta terdistribusi dengan baik ke jaringan tubuh. Akumulasi obat dalam jaringan tergantung pada jumlah aliran darah dan tingkat afinitas obat dalam jaringan. Obat yang memiliki afinitas tinggi pada jaringan cenderung mudah terakumulasi. Obat dengan tingkat koefisien partisi lemak tinggi cenderung terakumulasi dalam lemak atau jaringan lemak. Tetrasiklin merupakan obat dengan kelarutan lemak yang tinggi sehingga memiliki waktu eliminasi yang cukup lama dalam jaringan. Hal tersebut mengakibatkan tingginya kadar residu obat dalam jaringan (Wijayanti, 2010).

\section{Kesimpulan}

Ikan nila yang diedarkan di pasar tradisional Kota Yogyakarta terdeteksi mengandung residu tetrasiklin. Sebanyak 31\% sampel daging ikan nila mengandung residu tetrasiklin di atas batas maksimum residu. Berdasarkan hasil penelitian tersebut pengawasan terhadap kejadian residu antibiotik pada daging ikan konsumsi sangat diperlukan. Penelitian lanjutan terkait upaya pengurangan residu pada daging ikan nila sangat disarankan untuk meningkatkan mutu dan keamanan pangan asal hewan.

\section{Ucapan Terima Kasih}

Ucapan terima kasih disampaikan kepada Dinas Penanaman Modal dan Perizinan Pemerintah Kota Yogyakarta yang telah memberikan izin dalam pengambilan sampel ikan di pasar tradisional Kota Yogyakarta dan Departemen Farmakologi Fakultas Kedokteran Hewan Universitas Gadjah Mada yang telah menyediakan fasilitas selama penelitian.

\section{Daftar Pustaka}

Anastasia, Y. (2011) Teknik Analisis Residu Golongan Tetrasiklin dalam Daging Ayam secara Kromatografi Cair Kinerja Tinggi. Buletin Teknik Pertanian. 16: 68-71.

Ardita, N., Budiharjo, A. dan Sari, S.L.A. (2015) Pertumbuhan dan Rasio Konversi Pakan Ikan Nila (Oreochromis niloticus) dengan Penambahan Prebiotic. Bioteknologi, 12 (1): 16-21.

Association Of Official Analytical Chemists (AOAC) (2002) AOAC International Methods Comite Guidelines for Validation of Qualitative and Quantitative Food Microbiological Official Methods of Analysis. J. AOAC Int. 85: 1-5.

Badan Standardisasi Nasional (2000) Batas Maksimum Cemaran Mikroba dan Batas Maksimum Residu dalam Bahan Makanan Asal Hewan. SNI 016366-2000.

Badan Standardisasi Nasional (2009) Penentuan Residu Tertrasiklin dan Derivatnya dengan Kromatografi Cair Kinerja Tinggi (KCKT) pada Produk Perikanan. SNI 2354.11.

Barani, A. dan Fallah, A.A. (2015) Occurance of Tetracyclines, Sulfonamides, Fluoroquinolones, 
and Florfenicol in Farmed Rainbow Trout in Iran. Food and Agricultural Immunology. 26 (3): 423-424.

Canada, F.C., La Pena, A. M. and Espinosa-Mansilla, A. (2009) Analysis of Antibiotik in Fish Sample. Anal Bimal Chem. 395: 987-1008.

Codex Alimentarius Commision (2017): Maximum Residue Limits for Residues of Veterinary Drugs in Foods. Update as at the $40^{\text {th }}$ Session of the Codex Alimentarius Commision.

Daghrir, R. and Drogul, P. (2013) Tetracycline Antibiotics in the Environment: a Review. Environ Chem Lett. 11: 209-227.

Dasenaki, M.E. and Thomaidis, N.S. (2015) Multi Residu Determination of 115 Veterinary Drugs and Pharmaceutical Residu in Milk Powder, Butter, Fish Tissue, and Eggs Using Liquid Chromatography-Tandem Mass Spectometry. Analityca Chimica Acta. 880: 103-121.

Deck, D.H. and Winston, L.G. 2012. Tetracyclines, Macrolids, Clindamycin, Chloramphenicol, Streptogramins, and Oxazolidinones. Dalam: Katzung, B.G. (eds). Basic and Clinical Pharmacology Edisi ke 12. Lange, New York, 809-811.

Dewi, A.A.S., Whiddhiasmoro, N.P., Nurlatifah, I., Riti, N., dan Purnawati, D. (2014) Residu Antibiotika pada Pangan Asal Hewan, Dampak dan Upaya Penanggulangannya. Buletin Veteriner Denpasar. 26 (85).

Evaggelopoulou, E. and Samanidou, V. (2013) Development and Validation of an HPLC Method for the Determination of Six Penicillin and Three Amphenicol Antibiotics in Gilthead Seabream (Sparus Aurata) Tissue According to the European Union Decision 2002/657/EC. Food Chemistry. 136: 1322-1329.

Griffin, M.O., Fricovsky, E., Ceballos, G. and Villareal, F. (2010) Tetracycline: a Pleitropic Family of Compound with Promising Theurapetic Properties. Review of the Literature. Am Jurnal Physiol Cell Physiol. 299: 59, 548.

Kee, J.L. and Hayes, E.R. (1994) Farmakologi Pendekatan Proses Keperawatan Editor Yasmin Asih, Skp. ECG. Jakarta: 1058.
Kementrian Kelautan dan Perikanan (2016) Laporan Kinerja Kementrian Kelautan dan Perikanan Tahun 2015. Jakarta.

Kementerian Kelautan dan Perikanan (2018) Badan Karantina Ikan, Pengendalian Mutu dan Keamanan Hasil Perikanan. Jakarta.

Koleva, Y. 2014. Hepatotoxic Action and Influence on the Environment of some Antibiotics. Journal of Chemical Technology and Metallurgy. 49 (2): 157-162.

Lukistyowati, I. dan Syawal, H. (2013) Potensi Pakan yang Mengandung Sambiloto (Andrographis paniculata) dan Daun Jambu Biji (Psidium guajava) untuk Menanggulangi Bakteri Aeromonas hydrophila pada Ikan Baung (Mystus nemurus). Jurnal Akuakultur Rawa Indonesia. 1 (2):135-147.

Nurwigati, H.K. (2017) Berapa Banyak Konsumsi Ikan di Jogja. Jogja Politan. Diakses dari https://jogjapolitan.harianjogja.com/ $\mathrm{read} / 2017 / 10 / 19 / 510 / 861262 /$ berapa-banyakkonsumsi-ikan-lele-di-jogja.

Noga, E. (2010) Fish Disease Diagnosis and Treatment, Second Edition. Wiley-Blackwell. USA: 347383.

Nurhasnawati, H., Jubaidah, S. dan Elfia, N. (2016) Penentuan Kadar Residu Tetrasiklin $\mathrm{HCl}$ pada Ikan Air Tawar yang Beredar di Pasar Segiri Menggunakan Metode Spektrofotometri Ultra Violet. Jurnal Ilmiah Manuntung. 2 (2): 6

Okocha, R.C., Isaac, O.O. and Olufemi, B.A. (2018) Food Safety Impacts of Antimicrobial Use and Their Residues in Aquaculture. Public Health Reviews. 39 (21): 1-22.

Olatoye, I. and Afisu B. (2013) Antibiotic Usage and Oxytetracycline Residue in African Catfish (Clarias gariepinus in Ibadan, Nigeria). World Journal of Fish and Marine Sciences. 5 (3): 302-309.

Orlando, E.A. and Samionato, A.V.C. (2013) Extraction of Tetracycline Antibiotic Residu from Fish Fillet: Comparison and Optimization of Different Procedure Using Liquid Chromatography with Flouroscent Detection. Journal of Chromatography A. 1307 (2013) 111-118. 
Plumb, D.C. (1999) Veterinary Drug Handbook Edisi ke-3. South State Avenue, Iowa State University Press, 125-130.

Reda, R. M., Ibrahim, R. E., Ahmed, E. G. and ElBouhy, Z. M. 2013. Effect of Oxytetracycline and Florfenicol as Growth Promoters on the Health Status of Cultured Oreochromis niloticus. Egyptian Journal of Aquatic Research. 39: 241248.

Republik Indonesia (2004) Peraturan Pemerintah Nomor 28 Tahun 2004 tentang Keamanan, Mutu, dan Gizi Pangan. Sekretariat Negara, Jakarta.

Rohman, A. (2009) Kromatografi untuk Analisis Obat. Graha Ilmu. Yogyakarta: 217-235.

Sekkin, S. and Cavit, K. (2011) Antibacterial Drug in Fish Farm: Application and Its Effect. Adnan Manderes Ubiversity Press. Turkey: 12.
Wang, J., MacNeil, J. D. and Kay, J. F. (2012) Chemical Analysis of Antibiotic Residues in Food. A John Wiley \& Sons. Inc. Publication. United States of America: 48-52, 75-79.

Wijayanti, A. D., Hakim, L., Widiyono, I. dan Irianti, T. (2010) Penentuan Efektifitas Oksitetrasiklin Melalui Parameter Farmakokinetik / farmakodinamik pada Plasma dan Jaringan Ayam Broiler. Jurnal Sain Vet. 11 (2): 119-125.

Yuningsih (2004) Keberadaan Residu Antibiotika dalam Produk Peternakan (Susu dan Daging). Lokakarya Nasional Keamanan Pangan Produk Peternakan. Balai Penelitian Veteriner. 48-55.

Zhao, J., Liu, Y., Liu, W., Jiang, Y., Su, H., Zhang, Q., Chen, X., Yang, Y., Chen, J., Liu, S., Pan, C., Huang, G. and Ying, G. 2015. Tissue-specific Bioaccumulation of Human and Veterinary Antibiotics in Bile, Plasma, Liver and Muscle Tissues of Wild Fish from a Highly Urbanized Region. Environmental Pollution. 198: 15-24. 